\title{
The Power of a Single Number: a Political History of GDP
}

Philipp Lepenies

(Columbia University Press, 2013, German version, English Translation)

\author{
Review by Prof. John O’Hagan \\ Fellow Emeritus (Economics) \\ Trinity College Dublin \\ Dublin, Ireland
}

This book, as the subtitle suggests, is a political history of what the author claims is the 'most powerful statistical figure in human history' namely GDP, or gross domestic product of a country. First published in German in 2013, the English translation by Jeremy Gaines appeared in 2016. It is a relatively short book, not just in terms of number of pages but also in terms of text per page.

As the author acknowledges, the book does not provide a comprehensive history of the concept of national accounts given that this had been done already. It focuses instead on the political contexts within which GDP arose and the decisive periods in which it gained influence. The topic is of particular interest to Irish readers perhaps given the recent extraordinary upward revisions to GDP, which got world-wide attention and some obloquy.

Lepenies traces the origins of GDP to 17th century England in the person of William Petty and his 'Political Arithmetick'. Petty enlisted as a physician in Cromwell's army and served in Ireland, where following the Irish rebellion of 1641 to 1651 large swathes of the country were divided up among the English occupying forces. For this, a land register and a map of Ireland were required, for which task Petty was eminently suited. He also 'under dubious circumstances... became one of Ireland's biggest landowners ... and as an ennobled member of Parliament, he vehemently defended the interest of the English settlers in Ireland' (p. 11). This short passage illustrates clearly the political economy focus of this book.

Petty's calculations were driven by political consideration as the title of his famous book implies. 'He wanted to show that on account of its wealth and resources, England ....was economically and militarily on a par with its two enemies' (pp. 16-17), France and the Netherlands. The theme of linking GDP measures to militaristic purposes recurs throughout the rest of the book.

The next major contribution to the development of GDP had to wait until Colin Clark (1905-1989), who did most of his work on collecting statistics in Australia. For him though 'economics was not independent of moral considerations. He advocated early marriage, lots of children and agricultural self-sufficiency' (p. 36)! As a result, in 1964, Pope Paul VI appointed him as economic adviser to the Vatican Commission on Birth Control and Clarke 'played a major role in justifying the ban on contraception, not on theological but on economic grounds' (p. 37). 
The book also examines the contributions of some other great economists of the time of Clark, including Keynes, Robbins and in particular Meade and Stone (both future Nobel Prize winners) in England, who can be most clearly linked to the work of Petty and Clark before them.

The next big leap forward though occurred in the US, through the work primarily of Kuznets (Nobel prize winner in 1971). A lengthy chapter follows on the 'triumphal forward march of gross national product' in the US. There is in particular coverage of a very interesting discussion at the time on whether or not expenditure on armaments lead to an increase or decrease in national income, something of direct political relevance given that the US had entered World War II with a more than fourfold increase in spending on armaments.

The book then turns to Germany. It was the advent of World War II which focussed minds there also on the need for reliable statistics. But the biggest influence interestingly was US economist John Kenneth Galbraith, who was 'tasked with statistically recording the war mobilization effort of the German economy and its destruction' (pp. 113-4). It was at the request of the US in fact that Germany later had to produce complete national statistics for the first time as part of the Marshall Aid Plan after the War.

This a beautifully written (and translated) book, with some very interesting narrative about key personalities and developments with regard to the central role that GDP had come to assume in the 20th century. The book though is rather lacking in any proper discussion of how GDP has been viewed since the War, especially as there has been several critical treatises of the concept of GDP and its links, if any, to happiness and well-being. There is also no discussion of the development of the multitude of other indicators now used to throw light on well-being, such as the UN's Human Development Index and the World Bank's World Development Indicators, for example life expectancy, crime statistics, connectivity, human resources and assets and so on.

In a sense the argument as to what should be included in GDP is today considered very secondary as to what extent GDP matches general well-being if at all. It is after all almost a hundred years ago that Pigou pointed out the anomaly with national income statistics that 'if a man marries his housekeeper, or his cook, the national dividend is diminished'.

Another thing to consider is that material living standards are measured by GDP/capita, not GDP. China may have the same level of GDP as the US today, but its GDP/capita is probably not more than one-quarter that of the US. Except for military purposes perhaps, it is then GDP/capita that is maybe the most 'important single number'. Besides, statistical offices today are charged with collecting much, much more data than on GDP: such as on the labour market, education, housing and health, demographics and so on.

Nonetheless, the measurement of GDP is a key function of national and international statistical offices around the world and the origins of the political controversies surrounding the measurement of this concept over the centuries make for compelling reading, especially when it is written in such an erudite, interesting and elegant way as in this book. 